\title{
Biological Safety of a Highly Purified 10\% Liquid Intravenous Immunoglobulin Preparation from Human Plasma
}

\author{
Caroline Goussen $^{1}$ (1) $\cdot$ Steve Simoneau ${ }^{2} \cdot$ Soline Bérend $^{1} \cdot$ Christine Jehan-Kimmel $^{1}$. \\ Anne Bellon ${ }^{1} \cdot$ Céline Ducloux $^{1} \cdot$ Bruno You $^{1} \cdot$ Philippe Paolantonacci $^{1}$. \\ Monique Ollivier $^{2} \cdot$ Ludovic Burlot $^{1} \cdot$ Sami Chtourou $^{1} \cdot$ Benoît Flan $^{2}$
}

Published online: 15 May 2017

(C) The Author(s) 2017. This article is an open access publication

\begin{abstract}
Background A highly purified $10 \%$ liquid intravenous immunoglobulin, IQYMUNE ${ }^{\circledR}$, has been developed using an innovative manufacturing process including an affinity chromatography step for the removal of anti-A and anti-B hemagglutinins.

Objectives The pathogen (viruses and prions) clearance efficacy of the manufacturing process and its robustness for critical steps were investigated.

Methods The manufacturing process of IQYMUNE $^{\circledR}$ includes two dedicated complementary virus reduction steps: solvent/detergent (S/D) treatment and $20 \mathrm{~nm}$ nanofiltration as well as two contributing steps, namely caprylic acid fractionation and anion-exchange chromatography. The clearance capacity and robustness of these steps were evaluated with a wide range of viruses (enveloped and non-enveloped) and with a model of human transmissible spongiform encephalopathies (TSEs).

Results The IQYMUNE ${ }^{\circledR}$ manufacturing process demonstrated a high and robust virus removal capacity with global reduction factors (RFs) of relevant and model viruses: $\geq 14.8 \log _{10}$ for human immunodeficiency virus type 1 (HIV-1), $\geq 16.9 \log _{10}$ for bovine viral diarrhoea virus (BVDV)/Sindbis virus, $\geq 15.7 \log _{10}$ for pseudorabies virus (PRV), $\geq 12.8 \log _{10}$ for encephalomyocarditis virus (EMCV) and $11.0 \log _{10}$ for porcine parvovirus (PPV). The
\end{abstract}

Benoît Flan

flan@lfb.fr

LFB BIOTECHNOLOGIES, Les Ulis, France

2 LFB BIOMEDICAMENTS, 3 avenue des Tropiques, BP 40305, 91958 Courtaboeuf Cedex, France process also exhibited a high removal capacity for the TSE agent with an overall RF of $\geq 12.9 \log _{10}$ due to the complementary actions of the caprylic acid fractionation, anion-exchange chromatography and nanofiltration steps. Conclusion Data from virus and prion clearance studies fully support the high safety profile of IQYMUNE ${ }^{\circledR}$, with a minimal reduction of $11 \log _{10}$ for the smallest and most resistant non-enveloped virus, PPV, and more than $12 \log _{10}$ for the TSE agent.

\section{Key Points}

Dedicated steps as well as contributive steps to virus and prion clearance are required for plasma-derived medicinal products.

The manufacturing process of IQYMUNE ${ }^{\circledR}$ demonstrated very high capacity of inactivation and/ or removal of viruses and prion.

\section{Introduction}

Plasma-derived medicinal products (PDMPs) play an important role in human medicine today with a number of purified proteins of major therapeutic interest treating several severe pathologies. Among these, intravenous immunoglobulins (IVIGs) represent the main product derived from plasma fractionation, and have an increasing need worldwide both in replacement therapy in primary and secondary immunodeficiencies and in an 
immunomodulation setting. Indeed, a number of autoimmune diseases, mainly neurologic, are successfully treated with IVIGs [1-4]. IQYMUNE ${ }^{\circledR}$ is produced by a manufacturing process based on caprylic acid fractionation and chromatography steps to achieve a high level of purity and safety while maintaining high yields of production, a critical point in a context of increasing demand. Of paramount importance for plasma-derived products is the assurance of product safety with regard to potential contamination by blood-transmissible pathogens such as viruses and prions, the causative agents of Creutzfeldt-Jakob disease (CJD) and its subsequently identified variant (vCJD). The safety of IQYMUNE $^{\circledR}$ relies on (1) the quality of the starting material, human plasma, ensured by the careful selection of donors and screening of the plasma for viruses; and (2) the ability of the manufacturing process to remove and/or inactivate a wide range of known and potentially emerging viruses as well as ensuring the removal of prions $[5,6]$. Validation of key biological safety process steps is essential in order to assess the virus/prion removal capacity with respect to these agents $[7,8]$. The robustness of critical parameters for dedicated safety steps also needs to be evaluated to ensure the consistent, robust inactivation/removal across production runs.

We report on the validation of the virus removal and/or inactivation capacity and prion removal by the manufacturing process of IQYMUNE ${ }^{\circledR}$. The contribution of four steps to virus clearance and three steps to prion clearance have been validated $-20 \mathrm{~nm}$ nanofiltration, caprylic acid fractionation and anion-exchange chromatography for viruses and prions, and solvent/detergent (S/D) treatment for viruses-providing an optimum safety profile for IQYMUNE $^{\circledR}$. Results of robustness studies conducted for the S/D treatment, $20 \mathrm{~nm}$ nanofiltration and caprylic acid fractionation steps are also provided.

\section{Materials and Methods}

\subsection{Pathogens and Cells}

The viruses and prion agents used in this study are listed in Table 1. A wide range of viruses and a $263 \mathrm{~K}$ scrapie hamster brain microsomal fraction were used. For the $263 \mathrm{~K}$ agent, clarified brain homogenate $(\mathrm{BH})$ from infected animals was centrifuged at $10,000 \mathrm{~g}$ for $10 \mathrm{~min}$ and the supernatant ultracentrifuged at $140,000 \mathrm{~g}$ for $60 \mathrm{~min}$ as previously described $[9,10]$. The pellet was then resuspended in $0.9 \% \mathrm{NaCl}$ or $5 \%$ glucose solution and stored at $-60{ }^{\circ} \mathrm{C}$ or lower until use. The cells used for virus titration and the assays performed are described in Table 1.

\subsection{Evaluation of Virus Reduction}

Studies were carried out at BioReliance in Stirling, Scotland. Prior to performing any virus infectivity assay, tests were performed to determine the first non-cytotoxic and/or non-interfering dilution. Viruses were quantified by endpoint dilution in 96-well plates with the appropriate cell line by monitoring the cytopathic effect. Virus titres were calculated using the Spearman-Kärber formula [12] or Poisson distribution (when no virus is detected) and reported as tissue culture infectious dose per $\mathrm{mL}\left(\mathrm{TCID}_{50} /\right.$ $\mathrm{mL})[12,13]$. In order to improve the limit of detection, large volume plating (LVP) (consisting of the inoculation of 96-well plate(s) with sample at first non-cytotoxic and non-interfering dilution) was also performed on process samples, which were expected to contain no or only a few virus particles.

\subsection{Evaluation of Prion Reduction}

Quantification of the transmissible spongiform encephalopathy (TSE) agent in process intermediates was achieved using both the Western Blot (WB) method and bioassay (in Golden Syrian hamsters). For WB, process samples were digested with proteinase $\mathrm{K}(\mathrm{PK})$, boiled in denaturation buffer and serially diluted five-fold before analysis. Optimal PK concentrations were assessed for each type of sample. Protease-resistant prion protein $\left(\mathrm{PrP}^{\mathrm{res}}\right)$ signals were revealed using the anti-prion protein (PrP) antibody 3F4 or the alkaline phosphatase-labelled version of the $3 \mathrm{~F} 4$ antibody. The titre of the sample analysed was determined by taking the $\log _{10}$ of the first dilution where no $\operatorname{PrP}^{\text {res }}(28 \mathrm{kDa})$ could be observed. For the bioassay, process samples were serially diluted ten-fold and inoculated to groups of six animals (one group per dilution). Animals were observed for at least 365 days. The number of animals with clinical signs allowed to calculate a titre $\left(\log _{10}\right.$ infectious dose $50 \%$ per $\left.\mathrm{mL}\left[\mathrm{ID}_{50} / \mathrm{mL}\right]\right)$ using the method of Spearman Kärber [12]. Prion studies were carried out at BioReliance in Glasgow and Stirling (Scotland) for spiking and WB experiments and at BioReliance in Rockville (MD, USA) for bioassays.

\subsection{Manufacturing Process}

The IgG purification process (see Fig. 1) is based on ethanolic fractionation and caprylic acid precipitation followed by filtration steps (Supradur 50P depth filtration and AKS 5 carbon filtration [PALL LIFE SCIENCES, Bad Kreuznach, Germany]). To inactivate enveloped viruses, the protein solution is then subjected to $\mathrm{S} / \mathrm{D}$ treatment $(0.3 \%$ [v/v] tri-n-butyl phosphate [TnBP] and $1 \%[\mathrm{w} / \mathrm{v}]$ 


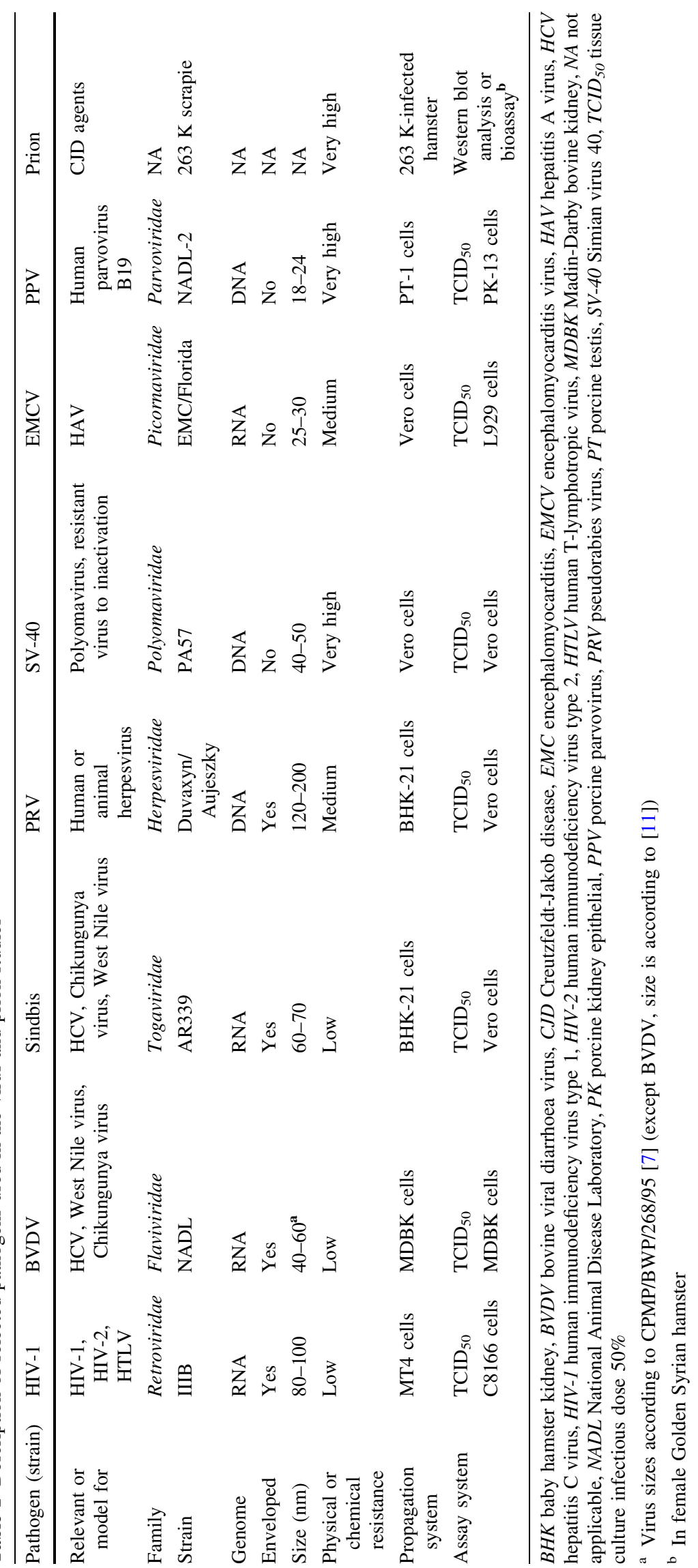


Fig. 1 IQYMUNE ${ }^{\circledR}$ manufacturing process: identification of virus inactivation/removal steps (dedicated steps in bold) and tested agents. $B V D V$ bovine viral diarrhoea virus, $E M C V$ encephalomyocarditis virus, HIV-1 human immunodeficiency virus type 1 , $P P V$ porcine parvovirus, $P R V$ pseudorabies virus, $S V-40$ Simian virus $40, T S E$ transmissible spongiform encephalopathy

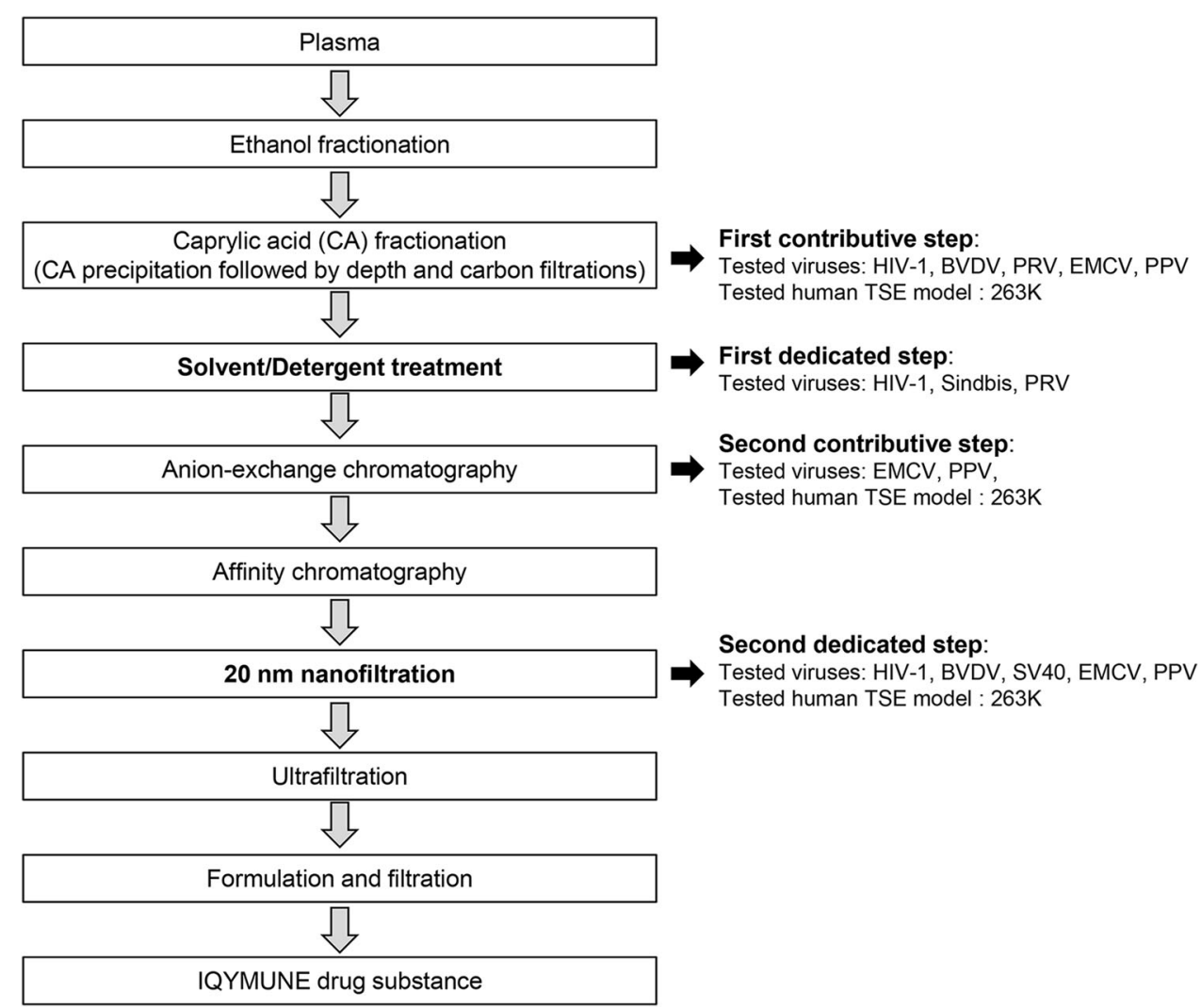

octoxinol for at least $6 \mathrm{~h}$ at $23 \pm 3{ }^{\circ} \mathrm{C}$ ). The $\mathrm{IgG}$ are then purified by a succession of two chromatography steps: an anion-exchange chromatography [Fractogel ${ }^{\circledR}$ EMD TMAE (MERCK MILLIPORE, Altdorf, Switzerland)] followed by an affinity chromatography $\left[\mathrm{HyperCel}^{\mathrm{TM}}\right.$ IsoA/IsoB (PALL BIOSEPRA, Cergy Pontoise, France)]. The solution is then filtered through the sequence of $0.1 \mu \mathrm{m}$-Ultipor ${ }^{\circledR}$ VF DV50 (PALL LIFE SCIENCES, Ilfracombe, England)-Planova ${ }^{\mathrm{TM}} 20 \mathrm{~N}$ (ASAHI KASEI, Nobeoka and Oita-shi, Japan) before the formulation stage.

\subsection{Laboratory-Scale Pathogen Clearance Studies}

Prior to undertaking the experiments, small-scale models of manufacturing processes were qualified for their relevance to industrial conditions. The critical operating parameters for each selected step are presented in Table 2. Process intermediates were spiked with selected viruses or the $263 \mathrm{~K}$ agent. For virus studies, the spiked material was prefiltered either on a $0.45 \mu \mathrm{m}, 0.2 \mu \mathrm{m}$ or $0.1 \mu \mathrm{m}$ filter, depending on the size of the selected virus, to remove potential aggregates. Due to the heterogeneous

Table 2 Critical operating parameters for selected manufacturing steps

\begin{tabular}{|c|c|c|c|c|}
\hline Step & Caprylic acid fractionation & $\mathrm{S} / \mathrm{D}$ treatment & $\begin{array}{l}\text { Anion-exchange } \\
\text { chromatography }\end{array}$ & $\begin{array}{l}20 \mathrm{~nm} \\
\text { nanofiltration }\end{array}$ \\
\hline Small-scale ratio & $1 / 9000^{\mathrm{a}}$ and $1 / 14300^{\mathrm{b}}$ & $1 / 10330$ & $1 / 7100$ or $1 / 7400$ & $1 / 4000$ \\
\hline \multirow[t]{3}{*}{$\begin{array}{l}\text { Critical operating } \\
\text { parameters }\end{array}$} & Caprylic acid to protein ratio $(\%)$ & $\begin{array}{l}\text { Concentration of } \mathrm{S} / \mathrm{D} \\
\text { reagents }\end{array}$ & Re-use resin & Protein load \\
\hline & $\begin{array}{l}\text { Volume of rinse for Supradur 50P } \\
\text { filter }\end{array}$ & Temperature & Column height & Temperature \\
\hline & & Incubation duration & & Pressure \\
\hline
\end{tabular}

$S / D$ solvent/detergent

a For precipitation and Supradur 50P filtration

b For AKS 5 filtration 
composition of the spiked material (resuspended precipitate), no filtration was performed before the caprylic acid fractionation evaluation. For prion studies, the spiked material was sonicated twice for 1-2 min before use. Before nanofiltration, the material was filtered with a $0.1 \mu \mathrm{m}$ filter, as carried out in the manufacturing process. Unless otherwise specified, clearance studies were performed in duplicate runs.

\subsection{Calculation of Reduction Factors}

The clearance capacity of a step (reduction factor $[R F]$ ) was calculated by taking the ratio of the quantity of pathogen detected in the load sample over the quantity detected in the fraction collected after the step, expressed as a logarithmic value $\left(\log _{10}\right)$. Three methods were used to calculate the final value of RF for a process step: (1) when no pathogen was detected in either of the two duplicate runs (both values are expressed with a ' $\geq$ '), the highest value of the duplicate RFs was selected; (2) when a pathogen was detected in only one of the two duplicate runs, the RF value of that run was selected; and (3) when a pathogen was detected in both duplicate runs, the mean value of the two RFs was chosen.

\subsection{Solvent/Detergent Treatment}

A mixture of solvent (TnBP) and detergent (octoxinol) was added to the spiked material and the solution was left with stirring during $6 \mathrm{~h}$. The treatment was performed in industrial conditions (S/D 1: $0.3 \%[\mathrm{v} / \mathrm{v}] \mathrm{TnBP}$ and $1 \%$ [w/v] octoxinol) at $25{ }^{\circ} \mathrm{C}$ and with lower concentrations of S/D (S/D 1/5: 0.06\% [v/v] TnBP and 0.2\% [w/v] octoxinol; S/D 1/100: $0.003 \%$ [v/v] TnBP and $0.01 \%$ [w/v] octoxinol) at 15 and $25{ }^{\circ} \mathrm{C}$, respectively. As massive interference was observed in the bovine viral diarrhoea virus (BVDV) assay system in the presence of the load material (very few or no residual infectivity was recovered in the spiked material and filtered spiked material), Sindbis virus was selected as another model for HCV.

\section{$2.820 \mathrm{~nm}$ Nanofiltration}

Clearance studies were evaluated under industrial conditions with the viruses and prions indicated in Fig. 1. Porcine parvovirus (PPV) was selected as the model virus for robustness studies, evaluating the effect of single or combined parameters (protein load, temperature and pressure). $\mathrm{RF}$ were calculated using the viral loads measured before and after the Planova ${ }^{\mathrm{TM}} 20 \mathrm{~N}$ filter (ASAHI KASEI BIOPROCESS, Brussels, Belgium). Hold controls were used to distinguish between inactivation due to the low $\mathrm{pH}$ and removal by filtration. After nanofiltration, the integrity of the filter was verified according to the manufacturer instructions. Backflush samples were titrated to confirm the virus retention on the $20 \mathrm{~N}$ filter.

\subsection{Caprylic Acid Fractionation}

For the validation of the caprylic acid fractionation step, the spiked material was adjusted to proper $\mathrm{pH}(\mathrm{pH} 4.8)$ and a load sample taken for titration. Caprylic acid and filter aid were then added and following a defined contact time (at least $60 \mathrm{~min}$ ), the solution was filtered through the Supradur $50 \mathrm{P}$ filter (PALL France, Saint-Germain-en-Laye, France). The filtrate and rinse fractions were pooled (intermediate filtrate). Industrial conditions were investigated with viruses and prions as shown in Fig. 1. The AKS 5 filter (PALL France, Saint-Germain-en-Laye, France) was evaluated only with encephalomyocarditis virus (EMCV), PPV and prions. The filtrate and rinse fractions of the AKS 5 filter were collected and pooled (final filtrate). Robustness conditions were tested with PPV to investigate the effect of a lower and upper caprylic acid to protein ratio (90 and $110 \%$ of the target value) and extra rinse of the Supradur $50 \mathrm{P}$ filter. The retentate of the Supradur $50 \mathrm{P}$ filter was also titrated to assess the mechanism of virus clearance. RF were calculated for the Supradur $50 \mathrm{P}$ filter alone (with the extra rinse) and coupled to the AKS 5 filter. Hold samples were collected to evaluate the effect of the time and of the $\mathrm{pH}$ of the matrix.

\subsection{Anion-Exchange Chromatography}

The anion-exchange chromatography $\left[\right.$ Fractogel $^{\circledR}$ EMD TMAE (MERCK MILLIPORE, Altdorf, Switzerland)] was challenged with the spiked product subjected to S/D treatment to reproduce the chemical environment for the chromatography. This sample was then adjusted to the proper $\mathrm{pH}(\mathrm{pH} 9)$ and conductivity before loading onto the column. The parameters tested consisted of lower and upper gel bed heights (55 and 110\% of the target value) and gel aging by repeated use. The RF was calculated from the virus amounts in the eluate and load fractions.

\subsection{Sanitisation Procedure Used for Anion- Exchange and Affinity Chromatography Steps}

The sanitisation protocols of the anion-exchange $(1 \mathrm{M}$ $\mathrm{NaOH} / 1 \mathrm{M} \mathrm{NaCl}$ for $60 \mathrm{~min}$ at room temperature [RT]) and affinity (1 M NaOH for $30 \mathrm{~min}$ at RT) chromatography columns were investigated using a carryover protocol. The column was loaded with a virus-spiked in-process fraction and the complete chromatography cycle (including regeneration and sanitisation steps) was performed. A second chromatography cycle performed with a non-virus-spiked 
in-process fraction then provided a measure of the virus that remained attached to the column.

\section{Results}

\subsection{Virus Clearance Studies}

A summary of clearance data of the manufacturing process of IQYMUNE ${ }^{\circledR}$ is presented in Table 3. The data show a high viral reduction capacity with a minimum of $11 \log _{10}$ for small non-enveloped resistant viruses (PPV) and higher $\mathrm{RF}$ for larger and/or enveloped viruses. The results are described for each individual step in more detail in Sects. 3.1.1-3.1.4, 3.2 and 3.3.

\subsubsection{Solvent/Detergent Treatment}

As expected, the S/D treatment performed for $6 \mathrm{~h}$ provided very effective inactivation for enveloped viruses with RF of $\geq 4.4 \log _{10}, \geq 5.4 \log _{10}$ and $\geq 4.3 \log _{10}$ for HIV-1, Sindbis and pseudorabies virus (PRV), respectively. The inactivation kinetics, shown in Fig. 2, indicated that inactivation occurs within seconds $(\leq 1 \mathrm{~min})$ of the treatment.

\section{$3.1 .220 \mathrm{~nm}$ Nanofiltration}

The sensitivity of HIV-1 to low $\mathrm{pH}$, as shown by the lower virus titres in the load and hold samples, prevented us from measuring a RF with the $20 \mathrm{~nm}$ nanofilter for this virus. Due to its large size (120-200 nm), PRV was not considered relevant for a $20 \mathrm{~nm}$ filtration step. The RF measured with BVDV ( $\geq 6.4 \log _{10}$ ), a more resistant ( $<2 \log$ of virus inactivation was only observed with BVDV) and smaller enveloped virus than HIV-1, was taken as the RF for HIV and PRV for this step. The nanofiltration was very effective for non-enveloped viruses, with $\mathrm{RF}$ of $\geq 4.8 \log _{10}$, $\geq 5.9 \log _{10}$ and $3.5 \log _{10}$ for tested viruses SV-40, EMCV and PPV, respectively. The robustness of the $20 \mathrm{~nm}$ nanofiltration step was demonstrated using the smallest size virus, PPV. Higher pressure, higher protein load and lower temperature had no impact on this step with RF of $4.6 \log _{10}, 3.8 \log _{10}$ and $4.0 \log _{10}$, respectively. In contrast, at lower pressure, a trend toward lower efficacy was observed (RF range 2.7-3.8 $\log _{10}$; see Fig. 3).

\subsubsection{Caprylic Acid Fractionation}

For enveloped viruses, RF $\geq 4.0 \log _{10}, 5.1 \log _{10}$ and $\geq 5.0 \log _{10}$ for HIV-1, BVDV and PRV, respectively, were measured for the combined caprylic acid precipitation and Supradur $50 \mathrm{P}$ (PALL France, Saint-Germain-en-Lay, France) filtration steps.

For non-enveloped viruses [caprylic acid precipitation followed by Supradur 50P and AKS 5 filtration steps (PALL France, Saint-Germain-en-Laye, France)], complete reduction of EMCV was evidenced with very high RF $\left(\geq 5.6 \log _{10}\right)$. No or very low level of infectivity was detected for EMCV in the Supradur 50 P filtrate and no infectivity was recovered in the AKS 5 filtrate (Table 4). Similar levels of PPV clearance were observed between intermediate and final filtrate fractions (3.9 $\log _{10}$ and $3.7 \log _{10}$, respectively). The robustness of critical parameters (caprylic acid to protein ratio and extended rinsing applied to the Supradur $50 \mathrm{P}$ filtration) was investigated with PPV and showed no significant impact in comparison to the industrial conditions (RF of $4.6 \log _{10}$ and $3.8 \log _{10}$ compared to $3.8 \log _{10}$ under industrial conditions; see Table 4). No or very low levels of PPV were released from the Supradur $50 \mathrm{P}$ filter despite extended rinsing (data not shown).

Table 3 Overall viral reduction capacity of the IQYMUNE ${ }^{\circledR}$ manufacturing process

\begin{tabular}{|c|c|c|c|c|c|c|}
\hline & HIV-1 & BVDV & PRV & SV-40 & EMCV & PPV \\
\hline Model for & HIV & $\mathrm{HCV}$ & Herpes DNA EV (HBV) & Highly resistant NEV & HAV & Parvovirus B19 \\
\hline \multicolumn{7}{|l|}{ Step } \\
\hline Caprylic acid fractionation & $\geq 4.0$ & 5.1 & $\geq 5.0$ & NT & $\geq 5.6$ & 3.7 \\
\hline $\mathrm{S} / \mathrm{D}$ treatment & $\geq 4.4$ & $\geq 5.4^{\mathrm{a}}$ & $\geq 4.3$ & NA & NA & NA \\
\hline Anion-exchange chromatography & NT & NT & NT & NT & 1.3 & 3.8 \\
\hline $20 \mathrm{~nm}$ nanofiltration & $\geq 6.4^{\mathrm{b}}$ & $\geq 6.4$ & $\geq 6.4^{\mathrm{b}}$ & $\geq 4.8$ & $\geq 5.9$ & 3.5 \\
\hline Overall viral reduction capacity & $\geq 14.8$ & $\geq 16.9$ & $\geq 15.7$ & $\geq 4.8^{\mathrm{c}}$ & $\geq 12.8$ & 11.0 \\
\hline
\end{tabular}

$B V D V$ bovine viral diarrhoea virus, $E M C V$ encephalomyocarditis virus, $E V$ enveloped virus, $H A V$ hepatitis A virus, $H B V$ hepatitis B virus, $H C V$ hepatitis $\mathrm{C}$ virus, $H I V-1$ human immunodeficiency virus type $1, N A$ not applicable, $N E V$ non-enveloped virus, $N T$ not tested, $P P V$ porcine parvovirus, $P R V$ pseudorabies virus, $S / D$ solvent/detergent, $S V$ - 40 Simian virus 40

${ }^{a}$ Value from Sindbis virus (another model for HCV)

${ }^{\mathrm{b}}$ Estimated reduction factor, based on the value measured for BVDV a smaller virus

c Only one step evaluated 

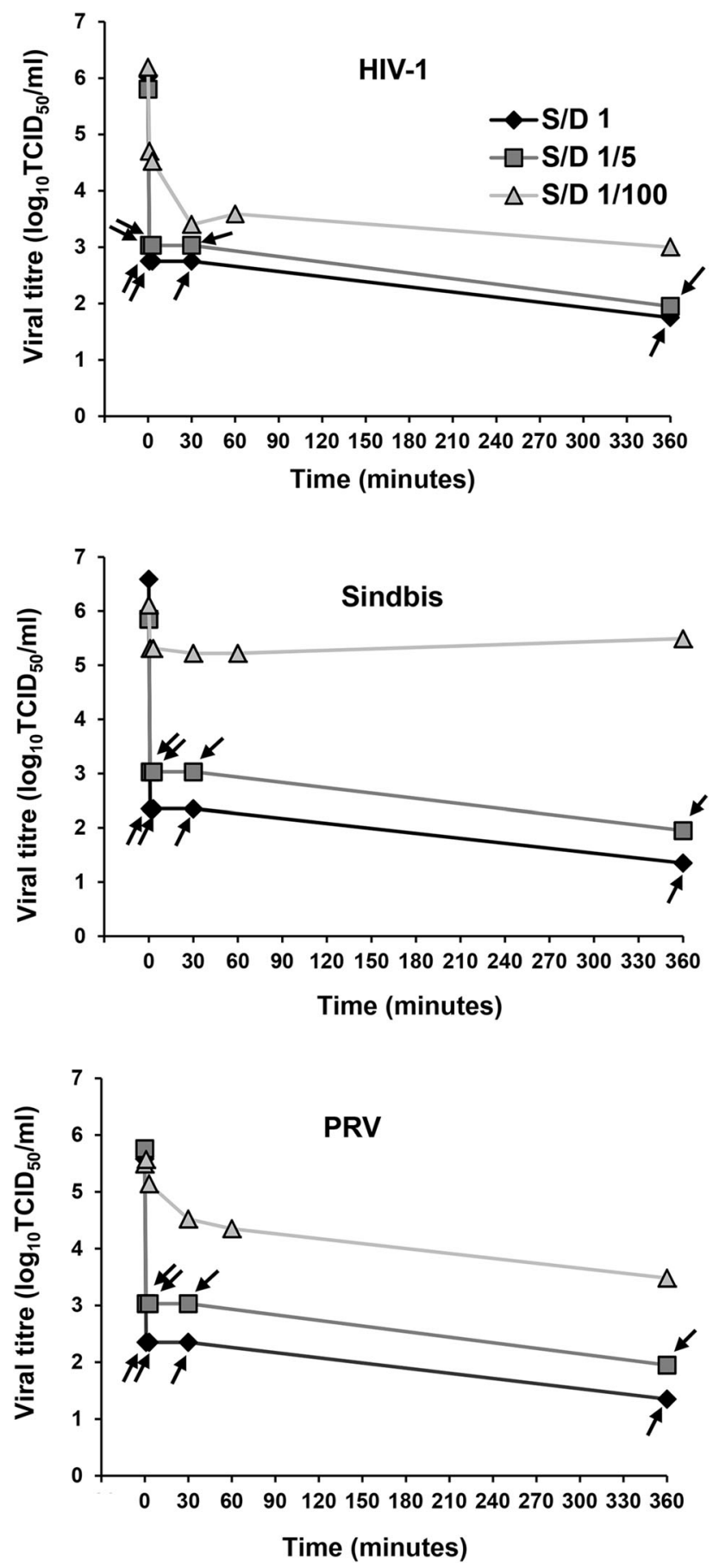

Fig. 2 Kinetics of inactivation of enveloped viruses at varying concentrations of solvent/detergent: S/D 1 industrial process conditions ( $0.3 \%$ tri- $n$-butyl phosphate/1\% octoxinol), S/D $1 / 5$ and S/D 1/100. Experiments were performed at $25{ }^{\circ} \mathrm{C}$, except for condition SD $1 / 5$ which was carried out at $15{ }^{\circ} \mathrm{C}$. Arrows point out timepoints with no virus detected. Average of duplicate runs for S/D 1 and 1/5; single run for S/D 1/100. HIV-1 human immunodeficiency virus type $1, P R V$ pseudorabies virus, $S / D$ solvent/detergent, $T C I D_{50}$ tissue culture infectious dose $50 \%$

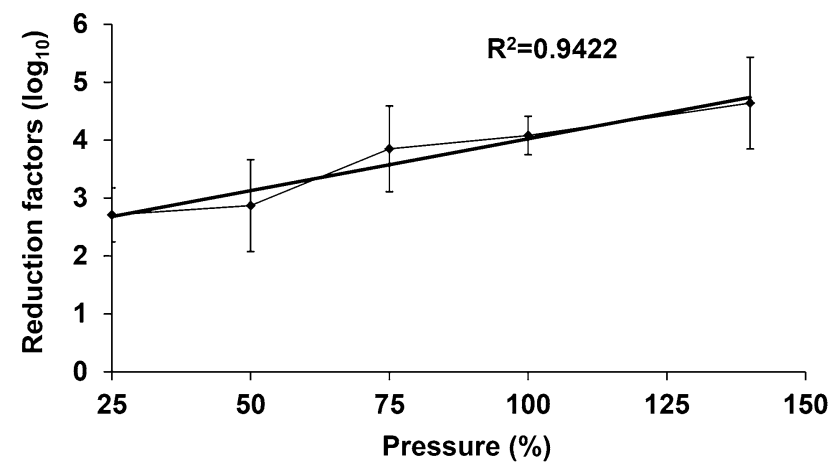

Fig. 3 Effect of pressure on the removal of porcine parvovirus by $20 \mathrm{~nm}$ nanofiltration. $P P V$ porcine parvovirus

\subsubsection{Anion-Exchange Chromatography}

The anion-exchange chromatography step reduction of non-enveloped viruses was evaluated with EMCV and PPV: both low and high gel bed height extremes (55 and $110 \%$ of the target value) were tested with new gel and only the high gel bed height ( $110 \%$ of the target value) was tested with end-of-life gel (100 cycles). Low reduction was observed for EMCV (RF of $1.3 \log _{10}$ and $2.1 \log _{10}$ for the 55 and $110 \%$ conditions, respectively). Contrarily, the step showed substantial PPV removal under both conditions (RF of $5.6 \log _{10}$ and $3.8 \log _{10}$; see Table 5). The virus removal was also evaluated with an end-of-life resin. No difference was observed between the two types of gel (EMCV: $1.6 \log _{10}$; PPV: $\geq 6.0 \log _{10}$; see Table 5).

\subsection{Sanitisation Procedure Used for Anion- Exchange and Affinity Chromatography Steps}

PPV, a highly resistant non-enveloped virus, was inactivated below detection for both gels, no PPV carryover was observed in the subsequent run ( $\mathrm{RF}$ of $\geq 5.6 \log _{10}$ and $\geq 6.6 \log _{10}$ were observed for the anion-exchange and affinity chromatography, respectively). The data confirm the efficiency of the sanitisation treatments to both chromatographic columns.

\subsection{Transmissible Spongiform Encephalopathy Clearance Studies}

Data from TSE clearance studies are shown in Table 6. The caprylic acid fractionation step was shown to be very effective in prion reduction with an RF of $\geq 4.0 \log _{10}$ by western blot, well-correlated to the bioassay ( $\geq 5.2 \log _{10}$ ). For the anion-exchange chromatography step, RFs of $\geq 2.7$ $\log _{10}$ (WB) and $\geq 3.9 \log _{10}$ (bioassay) were demonstrated. 
Table 4 Virus removal capacity of the caprylic acid fractionation step

\begin{tabular}{|c|c|c|c|c|c|c|c|}
\hline & \multicolumn{5}{|c|}{ Manufacturing conditions } & \multirow{2}{*}{\multicolumn{2}{|c|}{$\begin{array}{l}\text { Robustness study } \\
\text { PPV }\end{array}$}} \\
\hline & HIV-1 & BVDV & PRV & EMCV & PPV & & \\
\hline Caprylic acid to protein ratio (\%) & 100 & 100 & 100 & 110 & 110 & 90 & 110 \\
\hline \multicolumn{8}{|l|}{ Virus reduction factor $\left(\log _{10}\right)$} \\
\hline Supradur 50 P filtrate & $\geq 4.0$ & 5.1 & $\geq 5.0$ & 6.1 & 3.9 & 3.8 & 3.3 \\
\hline Supradur $50 \mathrm{P}$ filtrate with extra rinse & NT & NT & NT & NT & NT & 3.8 & 3.3 \\
\hline Final (AKS 5) filtrate & NT & NT & NT & $\geq 5.6$ & 3.7 & 4.6 & 3.8 \\
\hline
\end{tabular}

$B V D V$ bovine viral diarrhoea virus, $E M C V$ encephalomyocarditis virus, $H I V-1$ human immunodeficiency virus type $1, N T$ not tested, $P P V$ porcine parvovirus, $P R V$ pseudorabies virus
Table 5 Virus removal capacity of the anion-exchange chromatography step

\begin{tabular}{lrlr}
\hline Column height (\% of target value) & Cycle & \multicolumn{2}{l}{$\begin{array}{l}\text { Reduction factor } \\
\left(\log _{10}\right)\end{array}$} \\
\cline { 2 - 4 } & & EMCV & PPV \\
\hline 55 & 0 & 1.3 & 5.6 \\
110 & 0 & 2.1 & 3.8 \\
110 & 100 & 1.6 & $\geq 6.0$ \\
\hline
\end{tabular}

$E M C V$ encephalomyocarditis virus, $P P V$ porcine parvovirus

Concerning the $20 \mathrm{~nm}$ nanofiltration step, no scrapie-associated prion protein $\left(\mathrm{PrP}^{\mathrm{Sc}}\right)\left(\mathrm{RF} \geq 3.8 \log _{10}\right)$ was detected after passing through the whole filtering sequence $\left(0.1 \mu \mathrm{m}-\mathrm{DV} 50-\right.$ Planova $\left.^{\mathrm{TM}} 20 \mathrm{~N}\right)$. The overall prion reduction capacity for the IQYMUNE ${ }^{\circledR}$ product is higher than $12.9 \log _{10}$.

\section{Discussion}

Amongst the different preventive measures against the risk of transmission of pathogens for PDMPs, some are related to the starting material, such as the selection of donors, testing of donations and testing of plasma pools. In addition, the manufacturing processes, which include efficient inactivation and/or removal techniques, contribute greatly to the biological safety of PDMPs. This article describes the virus and prion clearance evaluation for four steps of the manufacturing process of IQYMUNE ${ }^{\circledR}$. The process includes two orthogonal-specific virus inactivation/removal steps - S/D treatment and $20 \mathrm{~nm}$ nanofiltration-as well as two steps with inherent virus/prion reduction capacity [13-17] - caprylic acid fractionation and anion-exchange chromatography.

S/D treatment is well-recognised as a highly efficient method for mitigating the risk of transmission of enveloped viruses by plasma products $[18,19]$. In the IQYMUNE ${ }^{\circledR}$ process, the S/D treatment performed under standard operating conditions $(0.3 \%$ TnBP and $1 \%$ octoxinol for $6 \mathrm{~h}$ at $23 \pm 3{ }^{\circ} \mathrm{C}$ ) resulted in complete inactivation of the three tested enveloped viruses within $1 \mathrm{~min}$. This is in agreement with its initial description by the New York Blood Center and recent literature $[19,20]$. The critical parameter of the $\mathrm{S} / \mathrm{D}$ treatment is the concentration of the inactivating reagents, while other parameters such as protein content, $\mathrm{pH}$ and temperature have been described to have little or no impact on virus inactivation [19]. The robustness of the S/D treatment was substantiated by the immediate inactivation of the same viruses under conditions of lower S/D concentrations $(1 / 5)$ and temperature $\left(15^{\circ} \mathrm{C}\right)$. For HIV-1, the inactivation kinetics remained similar even at $1 / 100$ th S/D concentration, confirming the high sensitivity of this virus to $\mathrm{S} / \mathrm{D}$ exposure.

Validation studies with various production processes around the globe have confirmed that nanofiltration on small pore size filters is a reliable and robust method/ technique for removing viruses and prions (for review see Burnouf et al. [21]). It can remove all types of viruses, including smaller and more resistant non-enveloped viruses. This technique is therefore complementary to the S/D treatment that inactivates only enveloped viruses. The nanofiltration step in the manufacturing process of
Table 6 Transmissible spongiform encephalopathy reduction capacity of the IQYMUNE $^{\circledR}$ manufacturing process

\begin{tabular}{lll}
\hline Step & Western blot & Bioassay \\
\hline Caprylic acid fractionation (precipitation followed by depth filtration) & $\geq 4.0$ & $\geq 5.2$ \\
Anion-exchange chromatography & $\geq 2.7$ & $\geq 3.9$ \\
$20 \mathrm{~nm}$ nanofiltration & $\geq 3.8$ & Not tested \\
Overall TSE reduction capacity & $\geq 12.9$ & \\
\hline
\end{tabular}

TSE transmissible spongiform encephalopathy 
IQYMUNE $^{\circledR}$ was effective in removing all tested viruses, including PPV, a model of human B19 parvovirus. The RF for this virus, the smallest in the series $(18-24 \mathrm{~nm})$, is $3.5 \log _{10}$. For the other two non-enveloped viruses investigated, complete removal was observed ( $\mathrm{RF} \geq 4.8 \log _{10}$ for SV-40 and $\geq 5.9 \log _{10}$ for EMCV) as anticipated. Concerning enveloped viruses, $a \geq 6.4 \log _{10}$ removal was evidenced for BVDV. Due to the sensitivity of HIV-1 and PRV to the operating conditions (low $\mathrm{pH}$ ), it was not possible to measure the removal capacity of this step for these viruses. However, the size exclusion mechanism of nanofiltration, as well as the data confirming significant removal of smaller viruses presented in this report is clearly in favour of the elimination of these larger viruses by this step. Moreover, the negligible impact of the robustness conditions (higher pressure, higher protein load and lower temperature) on the $20 \mathrm{~nm}$ nanofiltration performance observed with PPV reinforces the assurance that this step is highly efficient for virus removal. In contrast, reducing the pressure seemed to impact the nanofiltration removal since a tendency toward smaller RF was observed at lower pressures. For the pressure, the robustness studies lead, therefore, to a proven acceptable range of 0.6-1.1 bar.

Regarding the caprylic acid fractionation step, high RFs for enveloped viruses were obtained immediately after the precipitation and subsequent depth filtration step: $\geq 4.0 \log _{10}, 5.1 \log _{10}$ and $\geq 5.0 \log _{10}$ for HIV-1, BVDV and PRV, respectively. No virus was recovered in the precipitate (data not shown), indicating the viruses were inactivated during this step, as previously reported $[15,16,22]$. This step was also very effective in clearing non-enveloped viruses with RF of $\geq 5.6 \log _{10}$ for EMCV and $3.7 \log _{10}$ for PPV. For EMCV, clearance was almost complete (residual infectivity detected in one of the two runs) at the Supradur $50 \mathrm{P}$ step and therefore additional viral clearance by the AKS 5 filtration could not be evidenced. Similar levels of PPV infectivity were obtained in the intermediate and final filtrates, indicating that no further reduction was achieved by the AKS 5 filter. These findings are consistent with previous observations obtained under slightly different conditions with Reo-3, hepatitis A virus (HAV) and PPV [23]. Studies conducted to test critical parameters (upper and lower values of caprylic acid to protein ratio and extended rinsing of the Supradur $50 \mathrm{P}$ filter) demonstrated the robustness of this step with the most challenging virus, PPV. No PPV inactivation was measured in the hold controls and nearly all PPV infectivity was recovered in the precipitate sample, indicating that the reduction capacity of the step could be attributed to virus removal.

Because the S/D step was positioned just before the anion-exchange column, it was then judged more pertinent to evaluate this chromatography step exclusively with non- enveloped viruses. EMCV and PPV, selected as model viruses for HAV and B19, were spiked in in-process fractions and submitted to S/D treatment, in order to simulate the environmental conditions encountered by potential viral contaminants originating from the upstream process. Chromatographic removal of viruses from PDMP has long been documented [24]. The anion-exchange chromatography step was evaluated for two gel bed heights and with new and used gels. The clearance capacities of this anion-exchange chromatography column were high for PPV (3.8 $\log _{10}$ and $5.6 \log _{10}$ ) and relatively low but significant for EMCV (1.3 $\log _{10}$ and $\left.2.1 \log _{10}\right)$. After loading, no or a very low level of virus infectivity was detected in the unbound and washing fractions before elution, indicating binding of the viruses to the gel. Following the column regeneration step, the initial amount of virus was recovered in the regeneration fraction for both viruses, which demonstrated that partitioning was the mechanism of virus clearance. Results of viral clearance studies also demonstrated that end-of-life resin behaves identically (if not better) than new resin with regard to EMCV and PPV clearance.

Chromatography columns are sometimes used repeatedly and it is imperative that regeneration and sanitisation procedures in place be investigated under industrially relevant conditions to validate the absence of risk of carryover of potential contaminants from one production batch to the next. In the case of IQYMUNE ${ }^{\circledR}$, this was confirmed with both anion-exchange and affinity chromatography steps. The regeneration/sanitisation sequence, which includes for both resins a $1 \mathrm{M} \mathrm{NaOH}$ treatment, is known to be efficient and robust for virus inactivation $[25,26]$ and also reduces the prion risk as demonstrated recently by our group [27]. Based on prion removal data in the literature and in-house knowledge of the manufacturing process, three independent process steps with potential capacity to remove prions were identified in the IQYMUNE ${ }^{\circledR}$ manufacturing process: caprylic acid fractionation [23, 28], ion-exchange chromatography [17, 28, 29] and nanofiltration [28, 29-32]. The overall prion removal capacity was found to be more than $12.9 \log _{10}$, largely in excess of what is needed, according to current risk assessment calculations [32-35]. Moreover, no residual prion infectivity or protein was detected in any of the three steps validated, indicating that the real removal capacity of the process is likely much higher.

\section{Conclusion}

The manufacturing process of IQYMUNE ${ }^{\circledR}$ contains two specific and efficient orthogonal viral clearance steps (S/D treatment and $20 \mathrm{~nm}$ nanofiltration) and two contributive 
steps with substantial virus inactivation/removal capacity (caprylic acid fractionation and anion-exchange chromatography). The overall RF for non-enveloped viruses, which are more resistant to inactivation and/or elimination than enveloped viruses, was more than $11 \log _{10}$, providing a clear assessment of the safety of this product for all viruses. The high safety profile of this product also applies to prion clearance. Moreover, the validated regeneration/ sanitisation procedures for reused chromatography resins also contribute to the safety of IQYMUNE ${ }^{\circledR}$. Taken together, the data provided here offers thorough assurance of the high safety margin of the IQYMUNE ${ }^{\circledR}$ liquid IVIG product.

Acknowledgements The authors gratefully acknowledge Dr Henri Baron (deceased) and Dr Hannelore Willkommen for their valuable input and discussions. The authors wish to thank LFB process personnel for technical assistance. The authors also thank the virology and prion laboratories personnel of BioReliance (Scotland and USA).

\section{Compliance with Ethical Standards}

Funding Financial support for the conduct of the studies and preparation of the manuscript was provided by LFB.

Conflicts of interest The authors (CG, SS, SB, AB, CD, BY, PP, $\mathrm{MO}, \mathrm{LB}, \mathrm{SC}$ and $\mathrm{BF})$ declare that they are employees of LFB, a pharmaceutical company that manufactures and commercialises IQYMUNE. CJ-K was employed by LFB at the time the experiments were carried out and the manuscript was prepared.

Ethical approval Viral and prion clearance studies were carried out in accordance with the principles of Good Laboratory Practice (as required by international regulatory guidelines) with a specialised Contract Research Organisation. Applicable international, national and/or institutional guidelines for the care and use of animals were followed at the place where animal studies were conducted.

Open Access This article is distributed under the terms of the Creative Commons Attribution-NonCommercial 4.0 International License (http://creativecommons.org/licenses/by-nc/4.0/), which permits any noncommercial use, distribution, and reproduction in any medium, provided you give appropriate credit to the original author(s) and the source, provide a link to the Creative Commons license, and indicate if changes were made.

\section{References}

1. Tellier Z. Intravenous immunogloblins: myth and reality. Isr Med Assoc J. 2005;7(12):762-7.

2. Hartung HP, Mouthon L, Ahmed R, et al. Clinical applications of intravenous immunoglobulins (IVIg)-beyond immunodeficiencies and neurology. Clin Exp Immunol. 2009;158(Suppl 1):23-33.

3. Sriaroon P, Ballow M. Immunoglobulin replacement therapy for primary immunodeficiency. Immunol Allergy Clin North Am. 2015;35(4):713-30.

4. Lunemann JD, Quast I, Dalakas MC. Efficacy of intravenous immunoglobulin in neurological diseases. Neurotherapeutics. 2016;13(1):34-46.
5. EMA. Note for guidance on plasma-derived medicinal products. EMA/CPMP/BWP/706271/2010. London: EMA;.

6. EMA. CHMP position statement on Creutzfeldt-Jakob disease and plasma-derived and urine-derived medicinal products. EMA/ CHMP/BWP/303353/2010. London: EMA; 2011.

7. EMA. Note for guidance on virus validation studies: the design, contribution and interpretation of studies validating the inactivation and removal of viruses. CPMP/BWP/268/95 (revised). London: EMA; 1996.

8. EMA. Guideline on the investigation of manufacturing processes for plasma-derived medicinal products with regard to VCJD risk. CPMP/BWP/CPMP/5136/03. London: EMA; 2004.

9. Foster PR, Welch AG, McLean C, et al. Studies on the removal of abnormal prion protein by processes used in the manufacture of human plasma products. Vox Sang. 2000;78(2):86-95.

10. Foster PR, Welch AG, McLean C, et al. Studies on the removal of abnormal prion protein by processes used in the manufacture of human plasma products. Vox Sang. 2000;78(2):86-95.

11. Knipe DM, Howley PM, editors. Fields Virology. 5th ed. Lippincott Williams \& Wilkins; 2006.

12. Finney DJ. The median lethal dose and its estimation. Arch Toxicol. 1985;56(4):215-8.

13. Reed LJ, Muench H. A simple method of estimating fifty percent endpoints. Am J Hyg. 1938;27:493-7.

14. Flan B, Arrabal S. Manufacture of plasma-derived products in France and measures to prevent the risk of vCJD transmission: precautionary measures and efficacy of manufacturing processes in prion removal. Transfus Clin Biol. 2007;14(1):51-62.

15. Korneyeva M, Hotta J, Lebing W, et al. Enveloped virus inactivation by caprylate: a robust alternative to solvent-detergent treatment in plasma derived intermediates. Biologicals. 2002;30(2):153-62.

16. Lundblad JL, Seng RL. Inactivation of lipid-enveloped viruses in proteins by caprylate. Vox Sang. 1991;60(2):75-81.

17. Thyer J, Unal A, Thomas P, et al. Prion-removal capacity of chromatographic and ethanol precipitation steps used in the production of albumin and immunoglobulins. Vox Sang. 2006;91(4):292-300.

18. Horowitz B, Prince AM, Horowitz MS, et al. Viral safety of solvent-detergent treated blood products. Dev Biol Stand. 1993;81:147-61.

19. Dichtelmuller HO, Biesert L, Fabbrizzi F, et al. Robustness of solvent/detergent treatment of plasma derivatives: a data collection from Plasma Protein Therapeutics Association member companies. Transfusion. 2009;49(9):1931-43.

20. Hellstern P, Solheim BG. The use of solvent/detergent treatment in pathogen reduction of plasma. Transfus Med Hemother. 2011;38(1):65-70.

21. Burnouf T, Radosevich M, Goubran HA, et al. Place of nanofiltration for assuring viral safety of biologicals. Curr Nanosci. 2005;1:189-201.

22. Johnston A, Uren E, Johnstone D, et al. Low $\mathrm{pH}$, caprylate incubation as a second viral inactivation step in the manufacture of albumin. Parametric and validation studies. Biologicals. 2003;31(3):213-21.

23. Trejo SR, Hotta JA, Lebing W, et al. Evaluation of virus and prion reduction in a new intravenous immunoglobulin manufacturing process. Vox Sang. 2003;84(3):176-87.

24. Burnouf T. Chromatographic removal of viruses from plasma derivatives. Dev Biol Stand. 1993;81:199-209.

25. Borovec S, Broumis C, Adcock W, et al. Inactivation kinetics of model and relevant blood-borne viruses by treatment with sodium hydroxide and heat. Biologicals. 1998;26(3):237-44.

26. Boschetti N, Wyss K, Mischler A, et al. Stability of minute virus of mice against temperature and sodium hydroxide. Biologicals. 2003;31(3):181-5. 
27. Bellon A, Comoy E, Simoneau S, et al. Decontamination of prions in a plasma product manufacturing environment. Transfusion. 2014;54(4):1028-36.

28. Cai K, Groner A, Dichtelmuller HO, et al. Prion removal capacity of plasma protein manufacturing processes: a data collection from PPTA member companies. Transfusion. 2013;53(9):1894-905.

29. Foster PR, Griffin BD, Bienek C, et al. Distribution of a bovine spongiform encephalopathy-derived agent over ion-exchange chromatography used in the preparation of concentrates of fibrinogen and factor VIII. Vox Sang. 2004;86(2):92-9.

30. Porte P, Aubin JT, Kimmel-Jehan C, et al. Efficient prion removal by $15 \mathrm{~nm}$ nanofiltration after solvent-detergent treatment and ion-exchange chromatography in the manufacture of a nanofiltered factor VIII. Hemophilia 2006;12(Suppl. 2):5.

31. Tateishi J, Kitamoto T, Mohri S, et al. Scrapie removal using Planova virus removal filters. Biologicals. 2001;29(1):17-25.
32. Yunoki M, Tanaka H, Urayama $\mathrm{T}$, et al. Prion removal by nanofiltration under different experimental conditions. Biologicals. 2008;36(1):27-36.

33. Afssaps. Analyse du risque de transmission de la variante de la Maladie de Creutzfeldt-Jakob (vMCJ) par les produits de santé d'origine humaine. Rapport de juillet 2009. http://ansm.sante.fr/ var/ansm_site/storage/original/application/419c130c7c1464b24d 6c8c462b73f731.pdf.

34. Bennett P, Daraktchiev M. vCJD and transfusion of blood components: an updated risk assessment. London: Department of Health; 2013.

35. Yang H, Gregori L, Asher DM, et al. Risk assessment for transmission of variant Creutzfeldt-Jakob disease by transfusion of red blood cells in the United States. Transfusion. 2014;54(9):2194-201. 